\title{
Editorial to the themed issue on focus on infectious disease
}

\author{
Peter Bonate ${ }^{1}$ (I)
}

Received: 3 March 2017/ Accepted: 5 March 2017/Published online: 10 March 2017

(C) Springer Science+Business Media New York 2017

It could be argued that modern drug development was built on the discovery and development of antibacterial drugs starting with the industrialization of penicillin in World War II. In the 1940s, aminoglycosides, tetracyclines, and $\beta$-lactams were developed. The 1950s saw the development of cephalosporins, macrolides and quinolones. The 1960s and 1970 built on these discoveries and led to the discovery and creation of many different drugs within these classes. But, excluding daptomycin and linezolid in the early 2000s, no other new antibiotic drug classes have been discovered since 1980. Further, since the 1980s there has been a steady dwindling of research into antibiotics and a decrease in the approval of new antibacterial agents by the Food and Drug Administration. For example, 30 new drugs were approved between 1983 and 1992, 17 between 1992 and 2002, and 8 from 2002 to 2012 [1]. What has led to this decline was not due to any one thing but due to a number of factors like the belief that the "war against pestilence [was] won" (2), ${ }^{1}$ that the current antibiotic armament was "good enough", and lack of financial incentives for companies to pursue further antibiotics.

Today, we now know that the war has not been won. The rise of drug-resistant bacteria is a cause of concern among medical professionals and is a topic in many news magazines and newspapers [3]. Recently, several government agencies have called for more research to encourage development of antibiotics [4] and have published priority lists to focus research on the most troubling pathogens [5]. To address these concerns, recent legislation, such as the Generating New Antibiotics Now (GAIN) act in 2011,

Peter Bonate

peter.bonate@astellas.com

1 Astellas Pharma Global Development, Deerfield, IL, USA designed to encourage new antibiotic discovery, has been approved [6]. Still, in 2016, only 37 new antibiotics were in development [7] compared to over 800 in development in 2015 for cancer [8].

I personally find the lack of research in the discovery of new antibiotics by the pharmaceutical industry to be an embarrassment. Our industry is frequently maligned by politicians and the public alike as being greedy. The greedy pharmaceutical company is a common villain in television and movies. The fact that so few drugs are in the pipeline, even with financial incentives like the GAIN act in place, only lends fuel to that fire. Humanitarian efforts to identify new drugs to treat drug resistant bacteria should be a major goal of our industry, not because it will help our public image, but because it's the right thing to do.

In years past, the Journal of Pharmacokinetics and Pharmacodynamics has periodically issued a clinically themed issue. In 2013, the theme was "Translational Modeling and Neuroscience" and in 2014, the theme was "Modeling the Immune Response to Infection." This year we continue this with this clinically themed issue on "Focus on Infectious Disease." It is well known that pharmacokinetic-pharmacodynamic modeling can improve the efficiency of drug development and is crucial in identifying "the right dose, in the right patient, at the right time." The articles in this themed issue are meant to highlight some of the current research being done utilizing pharmacokinetic-pharmacodynamic modeling in the area

\footnotetext{
${ }^{1}$ As an aside, this quote is often repeated and has been widely attributable to Dr. William H. Stewart, Surgeon General of the United States, in 1967. However, recent research has shown that he never actually said it (Spellberg B (2008) Dr. William H. Stewart: mistaken or maligned? Clin Infect Dis 47; 294. It is repeated here because even today this quote is still used in the laypress [see the original article in [2] which was later corrected for its mistake].
} 
of infectious disease and were specifically chosen to highlight a broad range of applications. I would like to thank all the authors, and reviewers, who contributed their time and effort towards the success of this endeavor.

\section{References}

1. Spellberg B, Guidos R, Gilbert D, Bradley J, Boucher HW, Scheld MW, Bartlett JG, Edwards J Jr (2001) The epidemic of antibioticresistant infections. Clin Infect Dis 52(suppl 5):S328-S397

2. Specter M (26 December 2014) The New Yorker. http://www. newyorker.com/news/daily-comment/risks-viral-research. Accessed 2 March 2017

3. Harrell E (1 October 2009) The desperate need for antibiotics. Time. http://content.time.com/time/health/article/0,8599,1926853,00.html. Accessed 3 March 2017
4. NIADs Antibacterial Resistance Program: Current Status and Future Directions (2014) https://www.niaid.nih.gov/sites/default/ files/arstrategicplan2014.pdf. Accessed 2 March 2017

5. World Health Organization. Global Priority List of Antibiotic Research Bacteria to Guide Research, Discovery, and Development of New Antibiotics. http://www.who.int/medicines/publica tions/WHO-PPL-Short_Summary_25Feb-ET_NM_WHO.pdf?ua= 1. Accessed 2 March 2017

6. Brown D (2013) Is the gain act a turning point in new antibiotic discovery. Can J Microbiol 59:153-156

7. The Pew Charitable Trust (May 2016) Antibiotics currently in clinical development. http://www.pewtrusts.org/ /media/assets/ 2016/05/antibiotics-currently-in-clinical-development.pdf. Accessed 2 March 2017

8. Pharmaceutical Research Manufacturers Association (PhRMA) (2015) List of medicines in development for cancer. http://www. phrma.org/report/list-of-2015-medicines-in-development-for-cancer. Accessed 2 March 2017 